\title{
Relationship between Youth Unemployment and Economic Growth in Kenya
}

\author{
Mutua Daniel Katumo, James Maingi* \\ School of Economics, Kenyatta University, Kenya \\ Received December 5, 2019; Revised April 9, 2020; Accepted April 27, 2020
}

Copyright $\odot 2020$ by authors, all rights reserved. Authors agree that this article remains permanently open access under the terms of the Creative Commons Attribution License 4.0 International License

\begin{abstract}
Youth employment opportunities have been the priority by the Kenyan Government over the past years, and various policies have been implemented to assure the employment opportunities growth. Economic growth is reckoned to be essential since a positive growth rate will encourage inward investment and improve revenues, which can be spent on long-term public sector works. However, youth unemployment is a consistent problematic element in Kenya, affecting the economy to a large extent. The general objective of this study is to examine the relationship between youth unemployment and economic growth in Kenya. The specific objectives of the study are to investigate the causal relationship between youth unemployment and economic growth in Kenya and to analyze the effect of economic growth on youth unemployment in Kenya. The theories studied include the theory of surplus-value, Solow-swan model, Okun's law, and Keynesian theory, which explain the aspects of unemployment and economic growth. Secondary data was collected and used to illustrate the relationship between the variables, while the methodology used was the Granger causality test and OLS. A unidirectional causal relationship existed linking the two variables, where the lags of economic growth granger cause youth unemployment, and the coefficient between the two variables was positive. Hence Okun's law coefficient didn't apply when it comes to youth unemployment as opposed to the overall unemployment. However, the coefficient was statistically significant.
\end{abstract}

Keywords Youth Unemployment, Keynesian Theory

\section{Introduction}

\subsection{Youth Employment Challenge}

The current African generation absorbed in the labor market is the most educated ever. However, many aspects of the job opportunities and stipends differ from their parents' generation, and is worse in some countries (Filmer \& Fox, 2014).

Individuals living in rural areas and small towns are the most affected due to being illiterate, and the areas exhibit high poverty levels. Furthermore, they struggle in their adulthood to support their families compared to their counterparts in urban areas. The aspect of youth unemployment seems unmanning. However, African youth represent an enormous opportunity, especially now when the rest of the world population is aging rapidly. The youth can create jobs instead of seeking jobs. In the global market place, the African youth labor force can be a significant asset. However, to realize this potential, a greater understanding needs to be acquired to benefit from the asset. In studying the youth employment challenge in all dimensions, that is, demographic, economical, and social, and analyzing the aspects that brought about the problem will create pathways for the youth towards a better life and the result will be excellent prospects for the countries they reside. (Filmer \& Fox, 2014).

Exceptional opportunities exist in sub-Saharan Africa, with the majority of the population below 25 years of age, and every year between 2015 and 2035, there will be half a million more 15-year-olds than the year before. In the meantime, the rest of the world population is or will be aging (United Nations, 2011).

Africa's youth bulge offers a range of opportunities. First, working-age labor produces the world's goods and services. Sub-Saharan Africa can be the leading supplier of the world's workforce, either by creating products and services in the region or by sending workers to areas with a shortage of workers (World Bank, 2008).

Kenya's constitution defines youth as persons between the ages of 18 to 35 . Kenya's population is predominantly young, where the youth constitute 35 percent of the population (The Republic of Kenya, 2018). Youth unemployment is a situation where individuals aged 18-35 
are earnestly seeking gainful employment to no avail. It is a significant concern since individuals who become unemployed in the first year of work become detrimental to society. At the same time, it is problematic not only for the unemployed persons but also for the economy as a whole (Salvador \& Killinger, 2008). It is strenuous to envision how the youth can break even on their own in a country where they are expected to take care of themselves through valid income-generating ventures. KNBS survey indicated that seven million Kenyans are unemployed whereby, 1.4 million are hopelessly looking for a job. At the same time, others have given up on job search, with some going back for further studies.

To fully understand youth employment difficulties, one has to focus on the entire scope of activities which the youth may engage once they have gained knowledge to the point school is no longer the only choice. They may choose to take part in domestic activities or look for a well-paying job. Once they switch their mindset from school to job search, the economy is bound to have a high level of unemployed youth due to the period it takes for them to be absorbed in the labor market (Omolo, 2010).
During the period 1998 to 2005, the overall unemployment rate declined from 15 percent to 12.5 percent. But the allotment on youth unemployment rate shot up from 60 percent to 72 percent. The joblessness gauge was almost 40 percent for the youth, which was double that of adults, which stood at 21 percent (The Republic of Kenya, 2006). In 2005/06, KNBS indicated that youth unemployment rate for the youth ages 15-24 was 24 percent against the overall unemployment rate of 12.7 percent, it further stated the most affected were the young females.

From figure 1, the unemployment rate declined from the year 1993 to 1994.due to the implemented policies that focused on informal employment. In 1998, there was an introduction of the Jua kali voucher program, of which its implementation led to a decline in youth unemployment. Since the year 2000, the youth unemployment rate has been on the rise, society has many graduates seeking employment, but only a hand full are lucky to get the opportunities. The youth also face barriers in the labor market due to insufficient service record (Omolo, 2010) and (Coenjaerts, Ernst, Firtuny, \& Rei, 2009).

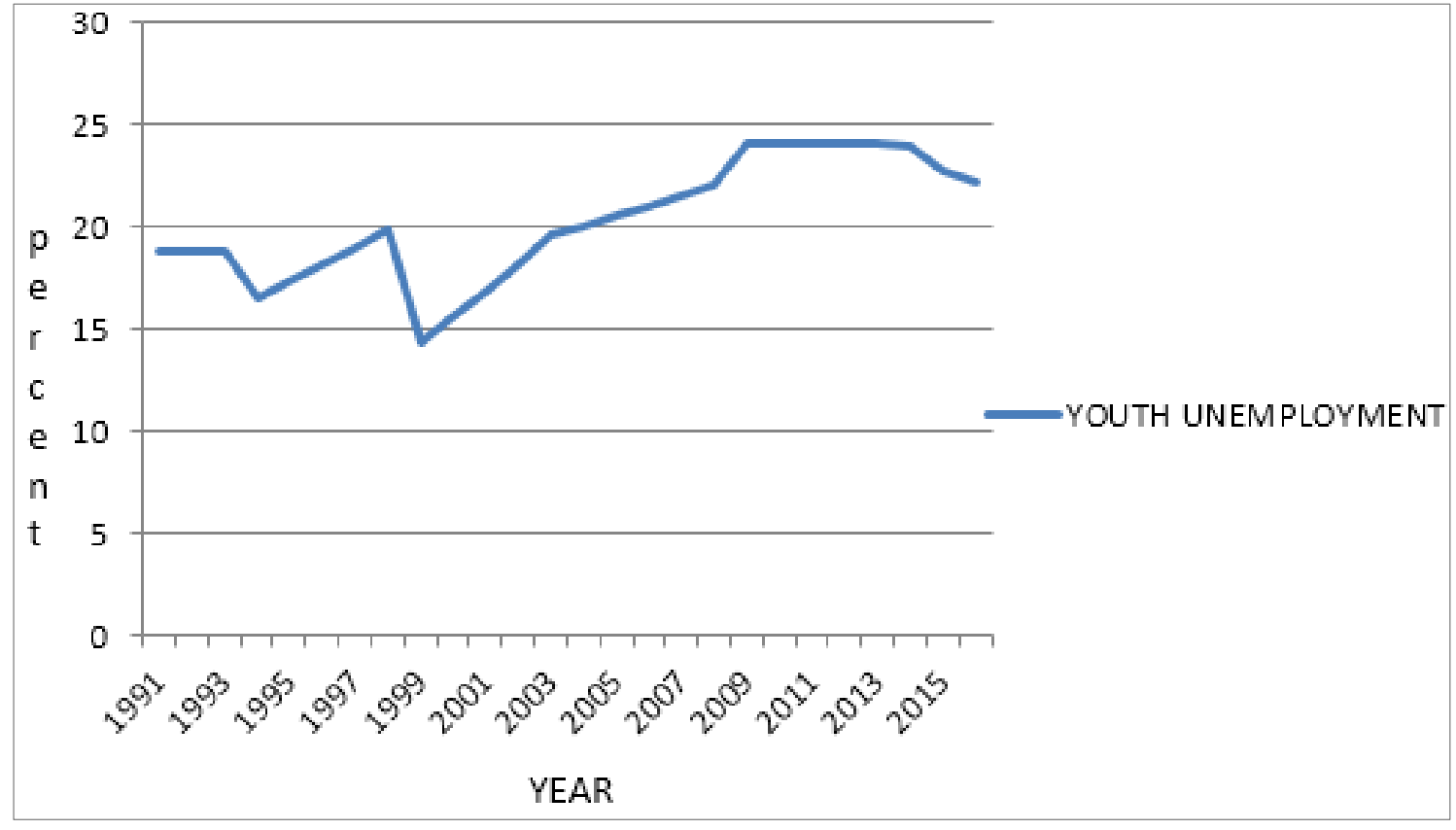

Source: Government of Kenya, Economic Surveys

Figure 1. Youth Unemployment in Kenya 
To policymakers, the high youth unemployment rate is an area of interest for various reasons. First, high youth unemployment implies inefficient use of unrecoverable resources. Secondly, high youth unemployment lowers consumption, which in turn harms the current growth, thereby harming human capital and private investment and, in the long run, harming future production capacities. Thirdly, high youth unemployment leads to human capital erosions. Youth become incompetent for staying long without work as their skills become outdated due to rapid technological changes and swift changes in the job market (Pissarides, 1992).

Communication skills barrier and the desire for quick money with less effort are a few of the obstacles towards the goal of reducing youth unemployment. Danner, Makau, and Nebe (2016) declared that all these do not paint real-life skills that can constructively prone the youth to employment opportunities and success in entrepreneurship. Therefore, the youth don't have mastery over the basic working ethics necessary for prosperous employment and entrepreneurship. These upheavals, together with the rigid labor market, don't provide adequate employment and favorable employment opportunities, forcing the youth to pursue other sources of livelihood through self-employment, such as owning a hand-cart (Danner, Makau, \& Nebe, 2016).

It is the responsibility of everyone to improve the Youth employment opportunities in the country by influencing change in the Entrepreneurial sector. The youth employment challenge can be blamed on the government as well as the political leaders together with the employers, not to forget the youth themselves. Situational factors such as corruption, nepotism, tribalism, and a substandard education system cause catastrophic youth unemployment. For instance, the education system doesn't churn graduates with the right skills for the job market (Danner, Makau, \& Nebe, 2016). In consideration of the link between weak economic conditions and high youth unemployment, the study will determine the relationship between economic growth and youth unemployment.

\subsection{Policies on Unemployment}

The Kenyan government has since independence come up with policies to curb unemployment in the Kenyan economy. The Kenyanization policy was among the first policies to be introduced by the Kenyan government, whereby it barred foreigners from the agricultural sector and rural trade (Republic of Kenya 1983). The fiscal and monetary policies suitable to curb unemployment were stated under the Sessional paper No 2 of 1985, whereby it encouraged the promotion of manufactured exports that were locally assembled and promoted favorable habitat for the broadening of the informal sector, which play a crucial role in creating employment.

The National Youth Service (NYS) was a vital institution for youth skills development. It was inaugurated in 1964 to train the youth on the skills required in the job market by instilling in them professional skills by attending technical and vocational institutes. It was an agreement between Kenya and the United Arab Emirates to provide 100,000 new job openings, youth between the ages of 18 to 22 were trained on suitable skills to gain access to the labor market. Furthermore, it was used by the government for the enrollment of the youth to the Kenya defense army. It provided rehabilitation and training to the poor and orphaned youth (The Republic of Kenya, 2008b).

One of the most relatively prosperous policy was the Kenya Jua kali voucher program. In 1997, its focus was to mold a training system to work better for the youth. The youth got training on micro and small enterprise projects, and it addressed market failures during the training by availing information, providing credit, and reducing location related barriers.

Gitonga (2008) study had numerous policies. For example, the development of the Jua Kali program as well as micro and small enterprises. These would create wealth and employment opportunities. The policies were from the Sessional Paper of 1992 and 1995. The main emphasis was on providing credit and expanding non-financial promotional programs.

Moreover, Sessional Paper number 7 of 2005, emphasized vocational training, apprenticeship, and internship programs to be installed into the education system. To aid in adjusting the change from school to the job market. The youth would also acquire the necessary experience.

In 2009, the Kazi Kwa Vijana program was launched to employ 300,000 youth yearly in areas of isolation and the civilized regions on labor-intensive public works projects (The Republic of Kenya, 2010). Some of the projects done in the rural areas include, but not limited to, the construction of dams, renovation of roads, digging boreholes, and planting trees. Constructing the kiosk, developing, and implementing waste management systems were some of the projects in the urban areas.

Kenya youth empowerment project (KYEP), which was proposed to enhance the Kazi Kwa Vijana voucher program by providing internship and youth training, was introduced in 2010. Its focus was to identify projects that would encourage community participation, institute clearer criteria in project selection, and develop a detective and evaluation system on elevating the labor content for the KKV program.

The Sessional Paper No. 10 of 2012, advocated for the rehabilitation of youth by training them on micro and small enterprises through the Technical, Industrial, Vocational and Entrepreneurship Training institutions, by providing training on skills that are consistent with the emerging technologies. The YEDF, together with the Uwezo fund, had the objective to advance loans to the young 
entrepreneur and render grants and interest-free loans to the women and youth. However, the two programs are yet to be effective. The expectation is that the initiative will have a positive and significant impact on unemployment amongst the youth.

Despite various policy proposals put in place to curb unemployment that deal with the demand and supply side of the economy, they are usually not executed. When enacted upon, no effort has been made to assess their worthiness (Wambugu, Munga, \& Onsomu, 2009). But in one way or another, different policy interventions had their successes and failures. However, youth unemployment continues to be the biggest challenge for Kenya. Thus there is a need to address youth employment challenge and bring into light how it's related to economic growth

\subsection{Economic Growth in Kenya}

The Kenyan economy experienced a downfall as the $20^{\text {th }}$ century concluded, in 1995/1996 the GDP dwindled from 4.9 percent to 2.4 percent in $1996 / 1997$ and further declined to 1.8 percent in $1997 / 1998$, this worsened in $1998 / 1999$ where it dropped to 1.4 percent and to 0.3 percent in $1999 / 2000$ (GOK, 2009a), because of the international aid freeze on lending, which in turn harmed commodity prices. As a result, its exhausted Kenya's current account and worsened the condition. On the positive side, the economy grew from a low of 2.8 percent in 2003 to 5.9 percent in 2005. It further inclined in 2006 and 2007 by increasing from 6.4 percent to 7.0 percent, respectively, which was the highest since the 1970s, where it grew at a mean of 7.2 percent. The improvement in the Kenyan economy was due to the execution of the economic and structural reforms under ERS performance.

Kenya vision 2030 provides the political, social, and economic blueprint that is to be attained by the year 2030 . The main goal under the economic plan was for the real GDP to grow in 2008 by 4.5 percent, in 2009 by 7.9 percent, in 2010 by 8.7 percent, and in 2011 by 9.1 percent and reach 10 percent by 2012 and be maintained at the 10 percent (The Republic of Kenya, 2008b). However, the economy grew at 1.5 percent in 2008 and 2.6 percent in 2009 , due to the post-election violence of 2007-2008. Even though in 2010 the economy grew at 5.6 percent, the growth was below par under the Kenya vision 2030.

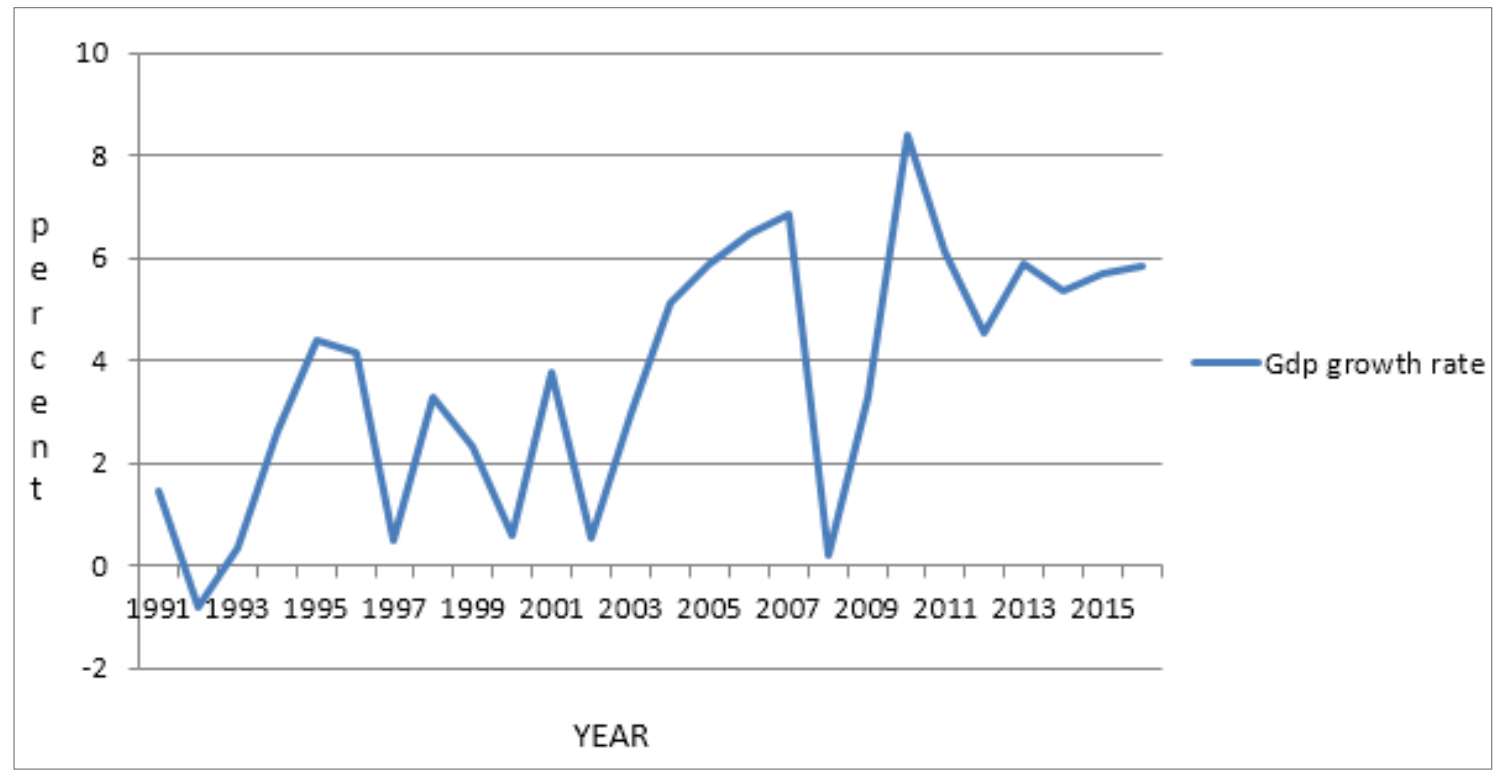

Source: World Bank

Figure 2. GDP growth rate for Kenya 


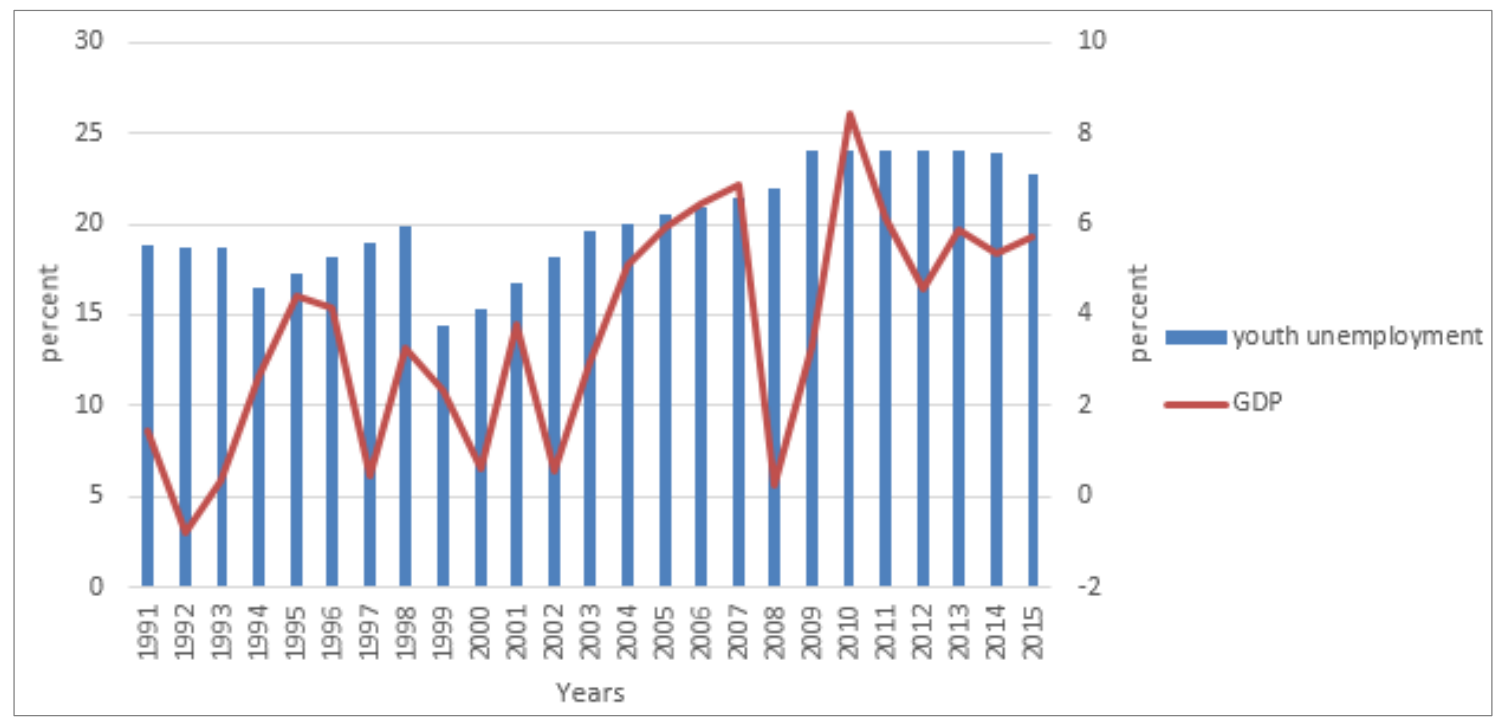

Source: Republic of Kenya (Economics Surveys, various)

Figure 3. Youth Unemployment and GDP growth trend rate

Youth unemployment and GDP growth aggressiveness show a distinctive nexus between improving economic growth and youth unemployment reduction is at its very best delicate. It is evident in figure 3 , that regardless of the rational increase in economic growth observed under the years in review to the labor force growth, it outgrew employment growth, bringing about a surge in youth unemployment, which is due to the high level of waged society and improved labor involvement. In 2003-2007 GDP grew mainly because of the strategies adopted by the Kenyan government, as stated under the sessional paper of 2003, which dealt with economic recovery for employment and wealth creation, (GOK, 2003). In 2007, the magnification seen on GDP was associated with the efficiency gain in the market.

High youth unemployment leads to liquidity constraints, thereby confining labor migration and resulting in lower economic growth (Andrienko \& Guriey, 2004). With elevated and unwavering youth unemployment levels, the young person will have low self-esteem and stunted life expectations and thereby, diminishing their belief in the society at large, (Ochsen \& Welsch, 2011). Some of the effects towards the youth on having lower confidence and experiencing socio-economic hardship include social disconnections leading to dispute disagreement, therefore, diminishing the market performance, (Mares \& Sirovatka, 2005). The outcome being a diminishing long-run growth.

Growth in labor supply will equally increase in output in the case where the new workforce is recruited with the unavailability of productivity growth. In the situation where job creation can't conform to the job-seeking, it can be articulated to the fall of the GDP underneath the rate of the labor force, implying unemployment will rise, (Toosi, 2012). Unemployment will fall in a situation where the output growth exceeds labor force growth. Employers will seek to fulfill the market demand and to do so; they will have to pull resources from the pool of unemployed youth.

There are various policies to curb youth unemployment and revamp the economic status, but there exist high levels of youth unemployment, and the economy isn't growing. Moreover, the Kenya vision 2030 economic blueprint not been attained since the inauguration, and the country has consummated stunted economic growth in the contemporary years. It is essential to scrutinize the relationship between youth unemployment and economic growth.

\subsection{Statement of the Problem}

Kenya's greatest challenge is youth unemployment, and the youth are the most valuable asset Kenya has and will continue to have in the future. Even so, various studies conducted and published indicate that there are numerous challenges faced by the youth despite the high levels of unemployed youth. A pile-up on Youth unemployment has been on the rise since the year 2000. The unemployment rate was 25 percent and 24 percent for the youth ages 15-24 and 20-24, respectively, twice the overall unemployment, which stood at 12.7 percent for the whole group, (Munga \& Onsomu, 2014).

Policies to curb youth unemployment, such as the Sessional Paper of 1992, 2005, and 2012 haven't been much sufficient as there persist high levels of youth unemployment. Furthermore, the technical education and vocational training institutes developed for the youth to train and gain skills to ease access to the labor market haven't assisted much in the reduction of youth unemployment, this encompasses a significant challenge.

Economic growth targets set under Kenya vision 2030 medium-term plan haven't been attained. For instance, the economy achieved a growth of 6 percent in 2006 and was to attain and maintain an increase of 10 percent by 
2012/2013. However, this wasn't met. Studies investigating the correlation between unemployment and economic growth have found different relationships exist between the variables. For instance, a study on the relationship between youth unemployment and economic growth, in Central and Eastern Europe by Karatekin, Gocer, and Yazar (2015), established that exclusive economic growth would not be sufficient in reducing youth unemployment in the situation it is found to be very severe, implying a negated relationship between the variables. Edward's (2007) study on the United States of America's economy found that when GDP grew, the rate of unemployment fell. However, when the GDP slowed down, the unemployment rate continued to fall. Seyfried (2004) found that, when an economy grew due to capital accumulation, employment increased, and the living standards improved, therefore reducing unemployment in the long run.

Okun's law indicates that a one percent surge in unemployment is due to a negative growth of two percent in GDP. A study on Kenya by Moses (2019), found that the coefficient of the two variables to be 0.12 instead of 0.3 as indicated in the Okun's law. Considering that the latter study focused on the overall unemployment, this study will be focusing specifically on youth unemployment and determine if the coefficient by Okun still stands, therefore, examine the causal relationship between youth unemployment and economic growth.

\subsection{Objectives of the Study}

The general objective of this study is to analyze the causal relationship between youth unemployment and economic growth in Kenya. However, the specific objectives of the study are

I To examine the causal relationship between youth unemployment and economic growth in Kenya.

II To analyze the effect of economic growth on youth unemployment in Kenya.

\section{Literature Review}

\subsection{Theoretical Literature Review}

\subsubsection{Surplus Value Theorem}

According to Karl Marx (1863), the theory explained the quantity of value produced by a worker beyond the necessary time. The price of any product decided the amount of labor it takes to produce it, which led to exploitation, which in turn led to wealth accumulation in surplus by the capitalist, subsequently dividing the society into rich and poor. With the increasing exploitation of labor by the capitalist, the profit accumulated, whereas the working class had nothing. The capitalist pampered themselves with their riches, whereas the poor working-class became poorer and poorer. Due to the exploitation and inhuman working condition, the workers became more and more alienated. Work for them was no longer the expression of the human himself. The worker became external to his work, more and more estranged from himself and the product. The worker then was alienated even from his fellowmen and from the community itself

The periodic crisis of mass unemployment was within the unstable capitalist system. It stated that with an unstable capitalist system, unemployment was an inherent and regular crisis of mass unemployment. A reserve army of labor was provided by the proletariat in the capitalist system to create downward pressure on wages. Unemployment was inherent because profits didn't increase, but on the flip side it was profitable to the capitalist because it lowered wages which were a burden to the prospective owners

From that point of view, lower wages were advantageous to the capitalist system since it diminished the economic rents but didn't benefit the worker. The capitalist unjustly manipulated the labor market by prolonging unemployment, which lowered the fair wages.

By abolishing capitalism and introducing a socialist or communist economy, it would lead to the elimination of unemployment and the improvement of wages provided to workers. Hence the capitalist system proved to be an invaluable tool to attain full employment.

\subsubsection{Solow-Swan Model}

The model was instituted in the 1950s by Robert Solow and Trevor Swan to explain growth economics. The model gives the production function as $Y=A_{t} F(K, L)$ where $Y$ is real output $K$ is capital, $L$ is the labor input, and $A_{t}$ is a measure of technology which is exogenous and taken to depend on the time.

$$
Y=F(K, L)
$$

Equation (1) satisfies Inada condition, all values of $K>0$ and $L>0, F(\cdot)$ exhibits positive but diminishing marginal returns for both capital and labor, which is $\frac{\partial F}{\partial K}>0, \frac{\partial^{2} F}{\partial K^{2}}<0, \frac{\partial F}{\partial L}>0, \frac{\partial^{2} F}{\partial L^{2}}<0$. The production function exhibits a constant return to scale, such that $F(\lambda K, \lambda L)=$ $\lambda Y$ that is, raising inputs by $\lambda$ will also increase aggregate output by $\lambda$. Letting $\lambda=\frac{1}{L}$ yields $\frac{Y}{L}=F\left(\frac{K}{L}\right)$. This assumption implies that (1) can be jolted down as (2) where $y=$ output per worker $(Y / L)$ and $k=$ capital per worker $(K / L)$

$$
y=f(k) \text { Where } f^{\prime}(k)>0 \text { and } f^{\prime \prime}(k)<0 \text { for all } k
$$

In a situation where an economy experienced a steady state, the output increased once productivity increased with continuous technological progress. When productivity increased at a constant rate, output also increased at an equivalent steady-state rate. The ramifications included growth in the model that occurred in two ways, widening 
the allotment of GDP invested or through technological advancement. Nonetheless, even with widening the allotment of GDP invested, capital ultimately converged constantly, abandoning the rate of growth of the output to emanate from technological advancement. With the availability of technology to the world and its advancement at a persistent momentum, all countries experienced a similar constant rate of growth. The share of GDP invested determined the GDP of a country. But the growth of the economy across the country was at a similar rate. In this model, wealthy nations were the ones that had infused the top allotment of GDP for a long time. Deprived nations became wealthy by adding the allotment of the GDP they invested. One cardinal prognosis of this model, largely conveyed out by this data, was that of "conditional convergence." The idea was that deprived nations would grow swiftly, therefore, leveling up to the wealthy nations. Still, the nations would need to have homogenous investment rates and access to similar technology.

It was viewed as an exogenous growth model since it didn't explain as to why different allotment of GDP in the capital invested by different countries and the persistent technological improvement over time. Technological advancement and investment rates were found to be exogenous. The value of the model was that it predicted the design of economic growth given the two rates.

\subsubsection{Okun's Law}

Okun's law (1962) determined the statistical relationship between the unemployment rate of a nation and its economic growth. The law described a statistical relationship that estimated a regression of unemployment and economic growth. Okun's law explained that an increase in the cyclical unemployment rate by one point resulted in a two-point negative growth in real GDP. The relationship between unemployment and real GDP growth varied with different countries and the span reviewed. The model was given by

$$
\Delta U_{t}=a-b * \Delta G D P_{t}
$$

Where $\Delta U_{t}$ is the change in unemployment level, $\Delta G D P_{t}$ is the change in real gross domestic product, $b$ is the Okun's coefficient which explains elasticity of unemployment rate in regards to gross domestic product

Okun's law implied a surge in the magnitude of the workforce or an improvement in labor productivity meant real gross domestic product grew without the net unemployment rates falling. Furthermore, the gross domestic product depended on the mass of labor employed in the production process. Therefore, a positive relationship existed between employment and real GDP. Given that the total employment population is from deducting unemployed population from the labor force, a negative relationship existed between output and unemployment.

\subsubsection{Keynesian Theory}

John Maynard, during the 1930s, came forth with a theorem with the desire to interpret the great depression. It recommended an increase in government disbursement and stunting the taxes to trigger demand and draw the economy from depression. The theory was viewed to be focusing on the demand-side since it anchored on short-run changes in the economy.

The classical economies preceded the Keynesian and held that cyclical swings in employment and economic output would be unpresuming and automatic. The classical indicated that a fall in price and wages would be due to a decline in aggregate demand, which would result in a deficiency in production and job market. A fall in inflation and improved stipend motivated the workers to make a capital investment and employ more individuals, therefore improving the employment levels and economic growth

On the flip side, the Keynesian theory was against lowering wages to the point of it inducing employers to employ because with demand being lower, the employer can dare to hire individuals to produce goods that would not be consumed. Furthermore, the poor business condition harmed companies leading to reduced capital investment, rather than companies taking full precedence of the situation to invest in new plants. In the long run, the effect would be a reduction in the overall expenditure and employment. The classical argued that the economy would return to a steady-state, but this was put to the test under the great depression, where the output was low, and unemployment was at high levels.

\subsection{Empirical Literature}

Javeid (2005), did a study to establish the association between GDP growth and the unemployment rate to ascertain the short-run behavior of the GDP growth model. Whereby the method used was the Error Correction Mechanism and Engle-Granger co-integration technique, the outcome was a dismissive correlation between the variables, but the variables had a long-run relationship. Moreover, the GDP growth rate in the long run adjusted swiftly towards the equilibrium.

Biyase and Bonga-Bonga (2010), did a research using the OLS technique to determine the South Africa paradox on growth and found that the relationship between growth and employment was contradicting. It implied that unemployment was an element for an output performance, which wasn't adequate to generate jobs, alternatively, leading to a gush in labor force participation rates. Furthermore, a study was done by Irfan et al. (2010), on the rational of Okun's law in Asian countries from the year 1980- 2006 using time series data, confirmed a long-run relationship between the two variables existed.

Stephen (2012), undertook a study in Nigeria to prove the correlation between urban unemployment crisis and economic growth. It integrated extraneous variables that included investment and inflation. The results indicated the 
existence of a negative correlation between the two variables. Moreover, in examining the relationship between employment and economic growth in Nigeria using the OLS technique, Sodipe, and Ogunrinola's (2011), study indicated that a positive and notable relationship existed between the employment levels and GDP growth rate.

Aliyu (2012), examined the output and unemployment dynamics in Nigeria. The research estimated the Okun's law coefficient using the transitory and permanent components of the real output series from the year 1970 to 2010. In the short run, there existed a negative correlation, while in the long-run, it was positive.

A study undertook by Al-habees and Rumman (2012), in Jordan and Arab countries for the period 2006-2011 in determining the link between economic growth and unemployment, using the comparison stimulation approach, established that a feeble relationship existed between the two variables for Arab countries and a strong relationship in Jordan. High growth rates resulted in a relative decline in the unemployment rate for the period studied.

Utilizing the co-integration and error correction model approach in examining the correlation between unemployment and productivity in Nigeria for the span 1986-2010, Amassoma and Nwosa (2012) undertook a study, whose outcome was the unit root and Johansen technique showed two different results. With one indicating the variables were co-integrated of different orders and the latter indicating the variables were co-integrated. Therefore, the short-run and long-run models revealed the variables had insubstantial dominance over the period studied.

A study done by Shaari, Hong, and Shukeri5 (2012), examined the relationship of FDI on the unemployment rate and economic growth in Malaysia. The span studied was from 1960 to 2010 . The analysis technique used was OLS, It established that FDI was significant in the reduction of unemployment and improving the GDP. The outcome revealed that a one percent incline in FDI resulted in a slump on unemployment by 0.009 percent, and the GDP grew by 1.219 percent.

To explore economic growth and employment relationship, Ozel, Sezgin, and Topkaya (2013) did a study on the G7 countries from the year 2001-2007 and later from 2008-2011. The panel regression analysis indicated that productivity and economic growth had a notable and vigorous significance in the depletion of unemployment for the period 2000-2007 and became irrelevant for the period 2008-2010. However, the outcome of economic growth had a diminishing reaction over unemployment.

The Toda Yamamoto technique was used by Leshoro (2013), to establish the causality direction between employment and economic growth from quarter one of 2000 to the third quarter of 2012 in South Africa. The result indicated the non-existence of causality between the variables. Bankole, Adiodun, and Fatai (2013), did a study in Nigeria that estimated the Okun's law coefficient, and scrutinized Okun's law credibility. It used the regression model and Engle granger for the period 1980-2008. The study found that the coefficient to be positive; hence, Okun's law didn't apply in the Nigerian economy.

A research done in Nigeria by Ditimi and Ifeakachukwu (2013), estimated the impact of unemployment on productivity growth. Time series data used spanned from 1986 to 2010; some of the extraneous variables included were inflation and government expenditure. The study exerted co-integration and error correction techniques. It discovered that unemployment had a beneficial effect on economic growth, and inflation had a positive and trivial effect on economic growth.

Yaumidin (2014) evaluated Okun's law on output and unemployment in the Indonesian economy, and the span covered was 1980 to 2013. Long-term results indicated an inelastic employment market demand existed mainly during the financial crisis. It implied that the Indonesian economy required high economic growth to make the labor demand elastic and absorb many more in the labor force, meaning the Okun's law was invaluable in Indonesia.

In Macedonia, Murat, Alit, and Luljeta (2014), estimated the link between economic growth and unemployment rate by executing the Okun's law. Four different models aided in determining Okun's coefficient, this included, differencing model, dynamic model, error correction model, and VAR estimation approach. The data used was quarterly for the period 2000-2012, the study found the Okun's laws didn't apply, and there was non-existence of a causal correlation between the variables.

Karatekin, Gocer, and Yazar (2015), probed the relation between youth unemployment and economic growth utilizing panel data analysis and co-integration for the period 2006-2012. Exclusive economic growth was not sufficient in reducing youth unemployment in the situation. It was found to be very severe, implying the non-existence relationship between the variables.

Applying VECM, granger causality and co-integration test, Eze, Emeka and Nwigboji (2016), probed the existence of a correlation linking unemployment and economic growth in the Nation Nigeria for the span 1980 to 2013. It mainly centered on the influence of unemployment on economic growth. The findings indicated a long-run relationship between the variables. Whereby, a unidirectional relationship between unemployment and economic growth existed.

Banda (2016), determined the relationship between unemployment and economic growth in South Africa for the span of 1994 to 2012. Using the Johansen co-integration technique, a long-run relationship among the variables was acknowledged. The results exhibited a positive correlation linking the two variables.

Eze, Emeka, and Nwigboji (2016), investigated the relationship between unemployment and economic growth in Nigeria. The study included the co-integration test, 
vector error correction model, and granger causality, where the period covered was 1980-2013. The study found that there existed a unidirectional correlation linking the two variables, which run from economic growth to unemployment.

The relationship between the youth unemployment rate and economic growth in low-income countries in sub-Saharan for the period 1991-2013 was researched by Orobosa, Asekome, and Ozemhoka (2017). The panel least square method and the OLS technique were applied to estimate the model. An inverse correlation existed under the panel results with positive results in some countries, hence contradicting the Okun's law.

Makaringe and Khobai (2018) investigated the trends and impact of unemployment on economic growth in South Africa over the period 1994 to 2016 on quarterly basis. The autoregressive distribution lag bounds test was used to compel the presence of a long-run correlation between the variables. The study suggested that there existed a long-run relationship among the variables.

\section{Methodology}

\subsection{Theoretical Framework}

The main concern of this study was to determine the relationship between youth unemployment and economic growth. Okun's law (1962) indicated that an increase in the cyclical unemployment rate by one point resulted in a two-point decline in real GDP. However, the relationship varied depending on the nation and span considered. Consider equation (3.1)

$$
\Delta U_{t}=a-b * \Delta G D P_{t}
$$

By incorporating investment as foreign direct investment and inflation, which were stated by Stephen (2012) as key contributors towards unemployment and economic growth, and taking into account wages under the theory of surplus-value, whereby the level of unemployed persons inclined with low wages. Changing the variable unemployment represented by $U_{t}$ to be youth unemployment $\left(Y U_{t}\right)$, equation 4 changed to;

$$
Y U_{t}=\alpha_{0}+\alpha_{1} G_{t}+\alpha_{2} W_{t}+\alpha_{3} I_{t}+\alpha_{4} F D I_{t}+\varepsilon_{t}
$$

Where $Y U_{t}$ is the Youth unemployment rate in Kenya, $G_{t}$ is GDP measuring economic growth in Kenya, $W_{t}$ is the wage employment levels in Kenya, $I_{t}$ is the inflation rate in Kenya, $F D I_{t}$ is the foreign direct investment levels in Kenya, $\varepsilon_{t}$ is the error term

\subsection{Empirical Model}

To attain the first objective of establishing the causal relationship between youth unemployment and economic growth. Granger causality test was carried out by lagging the variable of youth unemployment up to $\operatorname{lag} \rho$ and later lagging the variable of economic growth

$$
\begin{array}{r}
Y U_{t}=\alpha_{0}+\sum_{i=1}^{p} \beta_{i} Y U_{t-1}+\alpha_{1} G_{t}+\alpha_{2} W_{t}+\alpha_{3} I_{t}+ \\
\alpha_{4} F D I_{t}+\varepsilon_{t} \\
Y U_{t}=\alpha_{0}+\sum_{i=1}^{p} \beta_{i} Y U_{t-1}+\sum_{i=1}^{p} \beta_{1 i} G_{t-1}+\alpha_{2} W_{t}+ \\
\alpha_{3} I_{t}+\alpha_{4} F D I_{t}+\varepsilon_{t}
\end{array}
$$

Equation 3.4 showed that youth unemployment was a function of its past values and those of economic growth. It was used to determine whether economic growth Granger causes youth unemployment. The null and alternative hypothesis tested was;

$$
\begin{aligned}
& H_{0}: \beta_{1 i}=0 \\
& H_{1}: \beta_{1 i} \neq 0
\end{aligned}
$$

By rejecting the null hypothesis, it would imply that the economic growth Granger causes youth unemployment. Youth unemployment and economic growth were the dependent variables, while inflation, wages, and foreign direct investment were the independent variable. To express economic growth as the dependent variable in its lagged form and the lagged form of youth unemployment;

$$
G_{t}=\lambda_{0}+\sum_{i=1}^{p} \lambda_{i} G_{t-1}+\sum_{i=1}^{p} \ell_{i} Y U_{t-1}+\rho_{2} W_{t}+\rho_{3} I_{t}+
$$

$\ell, \gamma \lambda, \beta, \alpha$ are parameter estimates, and $\rho$ is the number of lagged observations.

Equations 8 was used to determine whether youth unemployment granger causes economic growth. The null and alternative hypothesis investigated was;

$$
\begin{aligned}
& H_{0}: \ell_{i}=0 \\
& H_{1}: \ell_{i} \neq 0
\end{aligned}
$$

By rejecting the null hypothesis, it would imply that youth unemployment granger causes economic growth

The following equation attained the second objective on the effect of economic growth on youth unemployment;

$$
Y U_{t}=\alpha_{0}+\alpha_{1} G_{t}+\alpha_{2} W_{t}+\alpha_{3} I_{t}+\alpha_{4} F D I_{t}+\varepsilon_{t}
$$

\section{Empirical Findings and Discussion}

Secondary data was collected to examine the relationship between youth unemployment and economic growth, and various diagnostic tests were done.

\subsection{Normality test}

Jarque-Bera test was used to check for normality to ensure that the residuals in the regression model behaved well. The null hypothesis was that the residuals are normally distributed. The results for the test were as below 


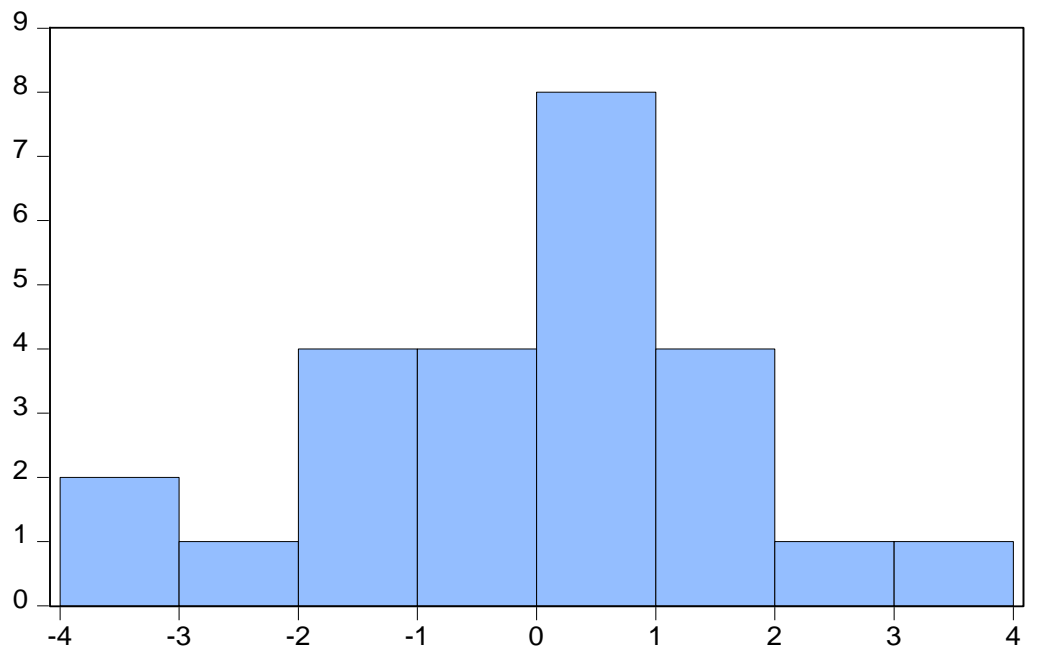

\begin{tabular}{|ll|}
\hline \multicolumn{2}{|l|}{ Series: Residuals } \\
Sample 1991 2015 \\
Observations & 25 \\
& \\
Mean & $2.30 \mathrm{e}-15$ \\
Median & 0.269402 \\
Maximum & 3.761957 \\
Minimum & -3.320677 \\
Std. Dev. & 1.713538 \\
Skewness & -0.047051 \\
Kurtosis & 2.646074 \\
& \\
Jarque-Bera & 0.139707 \\
Probability & 0.932530 \\
\hline
\end{tabular}

Figure 4. Normality Test (Source: Authors Computation)

The Jarque-Bera test Probability value of more than 0.05 implies the data is normally distributed. If it is less than 0.05 , it's not normally distributed. From the figure above, the probability was $0.932530>0.05$, implying the data was normally distributed.

\subsection{Autocorrelation}

The Breusch-Godfrey test was constructed to uncover the existence of autocorrelation. The null hypothesis in the Breusch-Godfrey test is that there exists no serial correlation. The table below presents the outcome.

Table 1. Breusch-Godfrey serial correlation LM test

\begin{tabular}{|l|l|}
\hline F-statistics 2.620508 & Prob f(1,19) 0.1220 \\
\hline Obs * R-squared 3.030118 & Prob chi-square (1) 0.0817 \\
\hline
\end{tabular}

Source: Authors computation

From the table, the probability for the F-statistics was $0.1220>0.05$. Hence the null hypothesis of no serial correlation wasn't rejected. Thus the residuals didn't exhibit any form of serial correlation.

\subsection{Multicollinearity}

The variance inflation factor method was used to test for Multicollinearity. A variance inflation factor that is greater than 10 indicates trouble with Multicollinearity. The outcome was as per the table below

Table 2. Variance Inflation Factor Test for Multicollinearity

\begin{tabular}{|c|c|c|}
\hline Variable & VIF & $\mathbf{1 / V I F}$ \\
\hline Economic growth & 1.454114 & 0.687704 \\
\hline Inflation & 2.680186 & 0.373108 \\
\hline Minimum wages & 1.954855 & 0.511546 \\
\hline FDI & 2.441672 & 0.409555 \\
\hline Mean VIF & $\mathbf{2 . 1 3 2 7 9 6 7 5}$ & \\
\hline
\end{tabular}

Source: Authors computation
The results indicated by table 2 shows that all variables had a variance inflation factor of less than 10 (VIF $<10$ ), indicating the absence of Multicollinearity. Hence, the null hypothesis of no Multicollinearity wasn't rejected.

\subsection{Stationarity Analysis}

The stationarity test was executed using the unit root test under the first difference. Later on, the co-integration of the variables. The t-statistics absolute values compared to the absolute critical values at all levels. If found to be higher than the critical values, then the null hypothesis of stationarity non-existence will be rejected.

Table 3. Unit Root Test for Stationarity

\begin{tabular}{|c|c|c|}
\hline \multirow{2}{*}{ Variable } & Form of Test & Conclusion \\
\cline { 2 - 3 } & $\begin{array}{c}1^{\text {st }} \text { difference (Test } \\
\text { statistic) }\end{array}$ & \\
\hline Youth unemployment & -4.714761 & Stationary \\
\hline Gross domestic product & -5.883444 & Stationary \\
\hline Minimum wage & -6.537301 & Stationary \\
\hline Inflation rate & -8.134799 & Stationary \\
\hline FDI & -10.47822 & Stationary \\
\hline Critical value at & -3.769597 & \\
$1 \%$ & -3.004861 & \\
$10 \%$ & -2.642242 & \\
\hline
\end{tabular}

Source: Authors Computation

By undertaking the unit root test on the variables first differenced values, the table indicated that each variable had a high absolute value of t-statistics compared to the critical levels. Hence, the study will not accept the null hypothesis of no stationarity. In this case, the study will further test for co-integration to determine the relationship between the variables. 
Table 4. Johansen Technique for Co-integration

\begin{tabular}{|c|c|c|c|c|}
\hline Hypothesized No. of co-integration & $\begin{array}{c}\text { Trace } \\
\text { statistics }\end{array}$ & $\begin{array}{c}\mathbf{0 . 0 5} \text { critical } \\
\text { value }\end{array}$ & $\begin{array}{c}\text { Max Eigen } \\
\text { Statistics }\end{array}$ & $\begin{array}{c}\text { 0.05 Critical } \\
\text { value }\end{array}$ \\
\hline None* & 85.90201 & 69.81889 & 51.18357 & 33.87687 \\
\hline At most 1 & 34.71844 & 47.85613 & 16.49266 & 27.58434 \\
\hline At most 2 & 18.22578 & 29.79707 & 9.850750 & 21.13162 \\
\hline At most 3 & 8.375031 & 15.49471 & 7.978449 & 14.26460 \\
\hline At most 4 & 0.396582 & 3.841466 & 0.396582 & 3.841466 \\
\hline
\end{tabular}

* - Denote reject of the null hypothesis at the level of 0.05

Source: Authors Computation

\subsection{Co-Integration}

The co-integration test was carried out using the Johansen technique of co-integration. The Trace test and Eigenvalue test statistical values compared to the 0.05 critical value. If found to be less that than the significant value of 0.05 , the study will reject the null hypothesis stating none existence of co-integration. The results are as shown in table 4.

The trace statistics and the max Eigenvalue statistics are below the 0.05 critical values in all the hypothesized co-integration except that for none*. Therefore, the study will fail to reject the null hypothesis implying the existence of no co-integration

\subsection{Causality between Youth Unemployment and Economic Growth}

The first objective of the study was to determine the causality between youth unemployment and economic growth in Kenya. The granger causality test was carried out and the results summarized in Table 5.

Table 5. Granger Causality Test

\begin{tabular}{|l|c|c|}
\hline Null Hypothesis & F statistics & Probability \\
\hline $\begin{array}{l}\text { The economic growth rate does } \\
\text { not granger cause youth } \\
\text { unemployment }\end{array}$ & 2.97484 & 0.1000 \\
\hline $\begin{array}{l}\text { Youth unemployment does not } \\
\text { granger cause the economic } \\
\text { growth rate }\end{array}$ & 0.94768 & 0.3419 \\
\hline
\end{tabular}

Source: Authors Computation

From table 5, the results indicate the lags of economic growth granger cause youth unemployment lags since the probability is equivalent to the significance level of 0.10 . Hence, there exists a unidirectional relationship between youth unemployment and economic growth with causality running from economic growth to youth unemployment.

\subsection{Effect of Economic Growth on Youth Unemployment}

The second objective of the study was to examine the effect of economic growth on youth unemployment. The OLS estimation technique was employed, taking into consideration that all variables were stationary at first difference. The OLS estimated the lags of both unemployment and GDP. The results are as in table 6.

Table 6. OLS Regression Results

\begin{tabular}{|c|c|c|c|}
\hline Variables & Coefficients & t-statistics & Probability \\
\hline $\begin{array}{c}\text { Economic growth } \\
\text { rate }\end{array}$ & 0.708084 & 3.801890 & 0.0011 \\
\hline Inflation rate & 0.179336 & 2.822544 & 0.0105 \\
\hline FDI & -0.233791 & -4.369566 & 0.0003 \\
\hline Minimum wages & 0.124711 & 1.522260 & 0.1436 \\
\hline Adjusted R-squared 0.661401 \\
\hline $\begin{array}{l}\text { F statistics 9.766750 } \\
\text { Probability value 0.000151 }\end{array}$ \\
\hline $\begin{array}{l}\text { Breusch Godfrey stat: F statistics 2.620508 } \\
\text { Probability value 0.1220 }\end{array}$
\end{tabular}

Source: Authors Computation

The variations among youth unemployment was explained by the experimental variables' variation $\mathrm{R}$-squared value of 66.14 percent. The R-squared of more than 50 percent was an indicator of a good fit model and described the changes in Youth unemployment. 33.86 percent excluded from the R-square explained the variation in youth unemployment attributed by variables not expressed in the equation. The F-statistic value of 9.766750 with a Prob of 0.000151 , imply it was statistically significant at 0.05 percent. It implied that in explaining the variations in youth unemployment; the model was perceived to be of significance. The Breusch Godfrey test F-statistic was 2.620508 , with a Probability of $0.1220>0.05$, implying there was no autocorrelation among the variables.

The results for the co-efficient between youth unemployment and economic growth rate was 0.7804, which was positive, hence in support of the study by Aliyu (2012), Banda (2016), and Ditimi, and Ifeakachukwu (2013). It implied Okun's law was invalid for Kenya in the case of youth unemployment. It is suggested that the lack of growth didn't explain the youth unemployment problem in Kenya. Hence, exclusive economic growth was not sufficient in reducing youth unemployment. However, it was statistically significant since the probability was $0.0011<0.05$.

The coefficient for FDI was negative and statistically significant at one percent, which was in support of the 
study by Shaari et al. (2012). It implied that an increase in FDI led to a decline in youth unemployment by 0.23 units. FDI led to increased efficiency and productivity, which in turn improved the level of human and physical capital, thereby it prompted job opportunities available and directly lowered youth unemployment levels.

For the case of wages, the coefficient was positive. But the probability was $0.1436>0.05$. Hence, it was statistically insignificant in predicting the trends of youth unemployment, rendering the theory of surplus-value invaluable in the Kenyan economy. The study further found that the coefficient between inflation and youth unemployment was positive, which was the inverse of Stephen's (2012) study, but it was statistically significant with Prob of $0.0105<0.05$. It would indicate that any attempt to control inflation would result in the reduction of youth unemployment though minimal.

\section{Conclusions and Policy Implications}

This study concluded that the Okun's law wasn't evident within the Kenyan economy for the case of youth unemployment since the coefficient between youth unemployment and economic growth was established to be 0.708 as opposed to 0.03 under the Okun's law. Furthermore, the inverse relationship exhibited by Okun didn't hold in the case of youth unemployment and economic growth. However, the coefficient between the two variables was statistically significant since the probability was $0.0011<0.05$.

The study has an important policy implication; the economic policies such as Sessional paper No 2 of 1985 would not have much effect on reducing youth unemployment in Kenya. However, economic policies more oriented to structural changes and reforms in the labor market would be most appropriate in the Kenya economy. Aggregate supply policies would be sufficient, such as lowering the taxes and wage increment.

\section{REFERENCES}

[1] Al-Habees \& Rumman. (2012). The Relationship Between Unemployment \& Economic Growth in Jordan \& Some Arab Countries.

[2] Aliyu, R. S. (2012). Macroeconomic Policy, Output \& Employment Dynamics in Nigeria: Is There Evidence of Jobless Growth.

[3] Amassoma \& Nwosa. (2012). The Impact of Unemployment Rate on Productivity Growth in Nigeria: An Error Correction Modelling Approach.

[4] Andrienko, Y., \& Guriey, S. (2004). Determinants of Interregional Mobility in Russia: Evidence from Panel Data. Economics of Transition, 1-27.
[5] Banda. (2016). The Impact of Economic Growth on Unemployment in South Africa (1994-2012).

[6] Bankole, Adiodun, S., \& Fatai, B. (2013). Empirical Test of Okun's Law in Nigeria. International Journal of Economic Practices \& Theories.

[7] Biyase \& Bonga-Bonga. (2010). The Effect of Unemployment on Economic Growth in South Africa (1994-2016).

[8] Coenjaerts, C. E., Ernst, C., Firtuny, M., \& Rei, D. (2009). Youth Employment.

[9] Danner, Makau, \& Nebe. (2016). Youth Unemployment in Kenya: A Time Ticking Bomb.

[10] Ditimi, A., \& Ifeakachukwu, N. P. (2013). The Impact of Unemployment Rate on Productivity Growth in Nigeria: An Error Correction Modelling Approach. International Journal of Economics \& Management Sciences, 1-13.

[11] Edward, S. (2007). How Useful is Okun's Law? Economic Review, 73-103.

[12] Eze, Emeka, \& Nwigboji. (2016). The Relationship Between Unemployment \& Economic Growth in Nigeria: A Granger Causality Approach.

[13] Filmer, D., \& Fox, L. (2014). Youth employment in sub-Saharan Africa. The World Bank.

[14] Gitonga. (2008). State of Youth Unemployment in Kenya. Brookings Institution.

[15] Irfan et al. (2010). Test of Okun's Law in Some Asian Countries: Co-integration Approach.

[16] Javeid. (2005). The Validity of Okun's Law: Empirical Evidence from Jordan.

[17] Karatekin, Gocer, \& Yazar. (2015). The Relationship between Youth Unemployment \& Economic Growth in Central \& European Countries: An Empirical Analysis Leman ERDAL.

[18] Leshoro. (2013). Does Economic Growth Lead Employment in South Africa.

[19] Makaringe \& Khobai. (2018). The Effect of Unemployment on Economic Growth in South Africa (1994-2016).

[20] Mares, P., \& Sirovatka, T. (2005). Unemployment, Labour, Marginalization \& Deprivation. Czech Journal of Economics \& Finance, 54-67.

[21] Max, K. (1863). Theories of Surplus Value. Progress Publishers.

[22] Moses, V. (2019). Does Okun's Law on Cyclical Unemployment Apply in Kenya? International Journal of Current Research, 1765-1770.

[23] Munga \& Onsomu. (2014). State of Youth Unemployment in Kenya.

[24] Murat, Alit, \& Luljeta. (2014). Econometric Estimation of the Relationship between Unemployment Rate \& Economic Growth of FYR of Macedonia.

[25] Ochsen, C., \& Welsch, H. (2011). The Social Costs of Unemployment: Accounting for Unemployment Duration. 
Applied Economics, 3999-4005.

[26] Omolo, J. O. (2010). The Dynamics \& Trends of Employment in Kenya. Nairobi: Institute of Economic Affairs.

[27] Orobosa, Asekome, \& Ozemhoka. (2017). Youth Employment \& Economic Growth: Lesson from Low-Income Countries in Sub-Saharan Africa.

[28] Ozel, Sezgin, \& Topkaya. (2013). Investigation of Economic Growth \& Unemployment Relationship for G7 Countries using Panel Regression Analysis.

[29] Pissarides, C. (1992). Loss of Skill During Unemployment $\&$ the Persistence of Employment Shocks. Quarterly Journal of Economics, 1371-1391.

[30] Salvador \& Killinger. (2008). An Analysis of Youth Unemployment in the Euro Area.

[31] Seyfried, W. (2004). Examining the Relationship Between Employment \& Economic Growth in the Ten Largest States. Southwestern Economic Review, 1-12.

[32] Shaari, M. S., Hong, T. H., \& Shukeri, S. N. (2012). Foreign Direct Investment \& Economic Growth Evidence. International Journal of Business \& Social Science.

[33] Sodipe, O. A., \& Ogunrinola, I. O. (2011). Employment \& Economic Growth Nexus in Nigeria. International Journal of Business \& Social Science.

[34] Stephen. (2012). Employment \& Economic Growth Nexus in Nigeria.

[35] Toosi, M. (2012). Labor force growth projections to 2020: A more slowly growing labor force. Monthly Labor Review, 443-464.

[36] United Nations. (2011). World Population Prospects: The 2010 Revision. New York: Department of Economic \& Social Affairs, Population Department.

[37] Wambugu, Munga, \& Onsomu. (2009). Unemployment in Kenya: The Situational Analysis.

[38] Yaumidin. (2014). Output \& Unemployment: Testing Okun's Law in Indonesia.

i A research project submitted to the department of applied economics in partial fulfillment of the requirement for the award of the degree of master of economics (finance) of Kenyatta University. 